\title{
Antimicrobial Activities and Antioxidant Properties of Bacillus Mojavensis I4 Lipopeptides and Application in the Biocontrol of Potato Dry Rots Caused by Fusarium Solani
}

Imen Ghazala ( $\square$ imenghazala@gmail.com )

Ecole Nationale d'Ingenieurs de Sfax https://orcid.org/0000-0003-2381-6769

Safa Charfeddine

ENIS: Ecole Nationale d'Ingenieurs de Sfax

Mariam Charfeddine

ENIS: Ecole Nationale d'Ingenieurs de Sfax

Radhia Gargouri

ENIS: Ecole Nationale d'Ingenieurs de Sfax

Semia Ellouze

ENIS: Ecole Nationale d'Ingenieurs de Sfax

Anisssa Haddar

ENIS: Ecole Nationale d'Ingenieurs de Sfax

\section{Research Article}

Keywords: Lipopeptide, Potato dry rots, Biocontrol, Biological activities, NRPS genes

Posted Date: February 16th, 2022

DOl: https://doi.org/10.21203/rs.3.rs-1324708/v1

License: (c) (1) This work is licensed under a Creative Commons Attribution 4.0 International License.

Read Full License 


\section{Abstract}

Lipopeptides are diverse metabolites produced by various bacterial and fungal genera known for their antimicrobial and surfactant activities with diverse environmental, pharmaceutical application and also agronomic applications as biocontrol agents. In this study, the presence of NRPS genes in Bacillus mojavensis 14 was confirmed by PCR and this bacterial strain could produce diverse lipopeptides which belonged to fengycin, and surfactin families. The antioxidant activity of 14 biosurfactants was determined through four different in vitro assays. Furthermore, antimicrobial activity assays indicated that 14 lipopeptides exhibited marked inhibitory activity against several bacterial and fungal strains. The 14 lipopeptides were effective in the biocontrol of Fusarium solani that causes potato dry rot disease. Preventive treatment decreased the fungi penetration by almost $80 \%$ after 15 days. This finding suggested promising application of 14 lipopeptides in potato tuber storage.

\section{Introduction}

Potato (Solanum tuberosum L.) ranks fourth among the most important food crops in the world after wheat and rice in terms of world food production and as an energy source (Thompson et al. 2009) According to FAO, potatoes production is estimated about 376 million tons in 2016 and classified as the fourth crops production after corn (1060 MT), wheat (794 MT) and rice (740MT) worldwide. Potato tubers, the edible part of the plant, are affected by many plant diseases caused by bacteria, fungi, viruses and nematodes (Toth et al. 2011). Fungal pathogens are the principal causes of crop losses before and after harvest (Strange and Scott 2005). Fusarium solani is one of the main soil-contaminating fungi that causes Fusarium wilt, which is a dry rot of tubers. This fungus penetrates in the potato tubers through wounds and causes drying and hardening. They form cavities lined with whitish mycelia. Dry rot of potatoes causes significant losses during storage.

Several effective fungicides had been used against pathogens, but as a long-term solution they were not effective owing to the expense, exposure risk, fungicide residue and environmental hazard concerns (Nguyen et al. 2013). Therefore, the use of biocontrol based on environment-friendly microorganisms represents an attractive alternative for plant disease management. Many research reports are available regarding, the use of Bacillus species as biocontrol agents (Mnif et al. 2015) and their derived biomolecules including lipopeptides to inhibit fungal spore germination (Mnif et al. 2015). Recently, lipopeptides were employed as suitable alternatives to synthetic medicines with lower toxicity, biodegradability and ecological compatibility. Indeed, Antioxidant, antimicrobial as well as antitumoral properties of lipopeptides are equally exploited in cosmetic and pharmaceutical fields (Tabbene et al. 2012). Biosurfactants are composed of 7 or $10 \mathrm{a}$-amino acids linked to one unique $\beta$-amino or $\beta$-hydroxy fatty acid with several families such as surfactin, iturin and fengycin (Akpa et al. 2001). Lipopeptides produced by Bacillus genus was synthesized by multi-enzyme templates know as non-ribosomal peptides synthetases (NRPSs). The present study aims to evaluate the antioxidant and antimicrobial activities of the lipopeptides produced by Bacillus mojavensis 14 and prove their potentiality in potato tuber rot biocontrol against Fusarium solani. 


\section{Materials And Methods}

\section{Plant material}

Potato tubers (Solanum tuberosum L) cv. Spunta produced and stored in our laboratory were selected free of wounds / rots and homogeneous in maturity / size, as much as possible.

\section{Culture conditions and lipopeptides extraction}

The bacterial strain, previously identified as Bacillus mojavensis 14 , was isolated from a soil sample collected from Sfax city, Tunisia. The production of 14 lipopeptides was performed in a liquid medium containing : glucose (30 g/L), glutamic acid (6 g/L), $\mathrm{KH}_{2} \mathrm{PO}_{4}(0.5 \mathrm{~g} / \mathrm{L}), \mathrm{K}_{2} \mathrm{HPO}_{4}(1 \mathrm{~g} / \mathrm{L}), \mathrm{KCl}(0.1 \mathrm{~g} / \mathrm{L})$, $\mathrm{MgSO}_{4}(0.5 \mathrm{~g} / \mathrm{L}), \mathrm{FeSO}_{4}(0.008 \mathrm{~g} / \mathrm{L}), \mathrm{CaCl}_{2}(0.05 \mathrm{~g} / \mathrm{L})$ and $1 \mathrm{~mL}$ of trace elements solution $(4.4 \mathrm{mg} / \mathrm{L}$ $\mathrm{ZnSO}_{4}, 3.3 \mathrm{mg} / \mathrm{L} \mathrm{MnSO}_{4}, 0.1 \mathrm{mg} / \mathrm{L} \mathrm{CuSO}_{4}$ and $1 \mathrm{mg} / \mathrm{L} \mathrm{NaBr}$ ) at pH 7 in $250 \mathrm{~mL}$ Erlenmeyer flasks containing $25 \mathrm{~mL}$ of culture medium and maintained for $48 \mathrm{~h}$ at $37^{\circ} \mathrm{C}$ and $180 \mathrm{rpm}$. Under these conditions, $B$. mojavensis 14 was able to produce approximately $2.1 \mathrm{~g} / \mathrm{L}$ of lipopeptides, estimated gravimetrically. The lipopeptides were recovered from the culture broth by centrifugation and acid precipitation (Liu et al. 2008).

\section{PCR detection and cloning of NRPS genes}

Five pairs of degenerate primers (Table 1) were used to amplify the genes encoding for surfactin synthetase, fengycin synthetase, bacillomycin synthetase, mycosubtiline synthetase and kurstakine synthetase as previously described (Abderrahmani et al. 2011). The PCR products were excised from Agarose gel and purified using the Pure Link Quick gel extraction Kit (Invitrogen) and cloned into the pGEM-T Easy vector (Promega) following the manufacturer instructions. Subsequently, cloned PCR products were sequenced using M13 universal sequencing primers and the obtained sequences was analyzed by BLASTX against the non redundant protein database on NCBI (https://blast.ncbi.nlm.nih.gov/Blast.cgi). 
Table 1

List and characteristics of primers used to detect lipopeptide biosynthesis genes.

\begin{tabular}{|c|c|c|c|}
\hline Primer name & Sequence of primer & Expected fragments size (bp) & lipopeptides \\
\hline As1-F & CGCGGMTACCGVATYGAGC & \multirow[t]{2}{*}{$419,422,425,431$} & \multirow[t]{2}{*}{ Surfactins } \\
\hline Ts2-R & АTBCCTTTBTWDGAATGTCCGCC & & \\
\hline Af2-F & GAATAYMTCGGMCGTMTKGA & \multirow[t]{2}{*}{$443,452,455$} & \multirow[t]{2}{*}{ Fengycins } \\
\hline Tf1-R & GCTTTWADKGAATSBCCGCC & & \\
\hline Am1-F & CAKCARGTSAAAATYCGMGG & \multirow[t]{2}{*}{416,419} & \multirow[t]{2}{*}{ Mycosubtilin } \\
\hline Tm1-R & CCDASATCAAARAADTTATC & & \\
\hline Abl1-F & GATSAWCARGTGAAAATYCG & \multirow[t]{2}{*}{$428,431,434$} & \multirow[t]{2}{*}{ Bacillomycins } \\
\hline Tbl1-R & ATCGAATSKCCGCCRARATCRAA & & \\
\hline Aks-F & TCHACWGGRAATCCAAAGGG & \multirow[t]{2}{*}{$1125,1152,1161,1167,1173$} & \multirow[t]{2}{*}{ Kurstakins } \\
\hline Tks-R & CCACCDKTCAAAKAARKWATC & & \\
\hline $\begin{array}{l}\text { Using IUPAC } \\
\text { or } C, R=A \text { or }\end{array}$ & A code $: Y=C$ or $T, M=A$ or $C, K=G$ & $\mathrm{~T}, \mathrm{~W}=\mathrm{A}$ or $\mathrm{T}, \mathrm{D}=\mathrm{G}, \mathrm{A}$ or $\mathrm{T}, \mathrm{S}=$ & \\
\hline
\end{tabular}

\section{Antioxidant activity}

\section{DPPH radical-scavenging capacity}

The DPPH radical-scavenging capacity of 14 biosurfactants was evaluated as described (Bersuder et al. 1998). Briefly, the aliquots of the different concentrations of the lipopeptides (1 to $10 \mathrm{mg} / \mathrm{mL}$ ) were mixed with $0.02 \% \mathrm{DPPH}$ in ethanol. The mixture was shaken vigorously, stood at room temperature for $60 \mathrm{~min}$ in the dark and the absorbance was measured at $517 \mathrm{~nm}$. A lower absorbance of the reaction mixture indicated higher DPPH free radical-scavenging activity. BHA was used as positive control and the DPPH radical scavenging capacity was calculated using the following formula:

Radical - scavenging activity $(\%)=\frac{A_{\text {Control }}-A_{\text {Sample }}}{A_{\text {Control }}} \times 100$

Where $A_{\text {control }}$ is the absorbance of the control reaction (containing all reagents except the sample) and $A_{\text {sample }}$ is the absorbance of sample reaction (with the DPPH solution). The experiment was carried out in triplicate with similar results and mean values were reported.

Ferric reducing antioxidant power (FRAP) assay 
The ability of 14 lipopeptides to reduce iron was determined as previously described (Yildirim et al. 2001) with slight modifications. $0.5 \mathrm{~mL}$ of 14 lipopeptides at different concentrations (from 1 to $10 \mathrm{mg} / \mathrm{mL}$ ) were mixed with $1.25 \mathrm{~mL}$ of $0.2 \mathrm{M}$ potassium phosphate at $\mathrm{pH} 6.6$ and $1.25 \mathrm{~mL}$ of $1 \%(\mathrm{w} / \mathrm{v})$ potassium ferricyanide solution. The reaction mixtures were incubated for $20 \mathrm{~min}$ at $50^{\circ} \mathrm{C}$ and stopped by the addition of $0.5 \mathrm{~mL}$ of $10 \%$ trichloroacetic acid. After centrifugation at $2700 \mathrm{~g}$ for $10 \mathrm{~min}, 1.25 \mathrm{~mL}$ of the supernatant solution were mixed with $0.25 \mathrm{~mL}$ of $0.1 \%$ ferric chloride and $1.25 \mathrm{~mL}$ of distilled water. After incubation at room temperature for $10 \mathrm{~min}$, the absorbance was measured at $700 \mathrm{~nm}$. The higher reducing power was indicated by the higher absorbance of the reaction mixture. Experiments were done in triplicates.

\section{Iron $\left(\mathrm{Fe}^{2+}\right)$ chelating activity}

For iron chelating activity, $0.1 \mathrm{~mL}$ of lipopeptides with a concentration range of 1 to $10 \mathrm{mg} / \mathrm{mL}$ was mixed with $0.45 \mathrm{~mL}$ of deionized water and $50 \mu \mathrm{l}$ of $2 \mathrm{mM}$ ferrous chloride. After $5 \mathrm{~min}$ of incubation at room temperature, the reactions were initiated by the addition of $200 \mu \mathrm{l}$ of ferrozine solution $(5 \mathrm{mM})$. The mixture was incubated for $10 \mathrm{~min}$ at room temperature and the absorbance measured at $562 \mathrm{~nm}$. Control tube was prepared with the same manner with substituting the lipopeptides by water. EDTA was used as a positive control and the percentage of inhibition of ferrozine- $\mathrm{Fe}^{2+}$ complex formation was determined as follows:

Chelating rate $(\%)=\frac{A_{\text {Control }}-A_{\text {Sample }}}{A_{\text {Control }}} \times 100$

Where $A_{\text {control }}$ is the absorbance of the control reaction and $A_{\text {sample }}$ is the absorbance of biosurfactants. Experiments were done in triplicates.

\section{DNA nicking assay}

DNA nicking assay was evaluated using empty pGEM-T easy plasmid (Promega). A mixture of $10 \mu \mathrm{L}$ of 14 lipopeptides ( 1 or $4 \mathrm{mg} / \mathrm{mL}$ ) and $0.5 \mu \mathrm{g}$ of plasmid DNA were incubated for $10 \mathrm{~min}$ at room temperature followed by the addition of $10 \mu \mathrm{l}$ of Fenton's reagent $\left(30 \mathrm{mM} \mathrm{H}_{2} \mathrm{O}_{2}, 50 \mu \mathrm{M}\right.$ L-ascorbic acid and $80 \mu \mathrm{M}$ $\mathrm{FeCl}_{3}$ ). After incubation for $5 \mathrm{~min}$ at $37^{\circ} \mathrm{C}$, the mixtures were analyzed by agarose gel electrophoresis.

\section{Antimicrobial activity analysis}

The antibacterial activities of 14 lipopeptides were tested against three Gram-negative (Escherichia coli ATCC 25922, Klebsiella pneumoniae ATCC 13883 and Salmonella enterica ATCC 43972) and four Grampositive (Staphylococcus aureus ATCC 25923, Enterococcus faecalis ATCC 29212, Listeria monocytogenes ATCC 43251 and Micrococcus luteus ATCC 4698) bacterial strains. The antifungal activities were evaluated against Rhizoctonia solani, Fusarium solani and Botrytis cinerea. 
Antimicrobial activity was investigated as previously described (Berghe et al. 1991). A culture suspension $(200 \mu \mathrm{L})$ of the tested microorganisms $\left(10^{8}\right.$ spores $/ \mathrm{mL}$ and $10^{6} \mathrm{cfu} / \mathrm{mL}$ of fungal and bacterial strains, respectively) was spread on potato dextrose agar medium and Luria-Bertani (LB) agar, respectively. Subsequently, $60 \mu \mathrm{l}$ of lipopeptides solution $(20 \mathrm{mg} / \mathrm{mL})$ were added to each well ( $5 \mathrm{~mm}$ diameter), punched in the agar layer, allowed to diffuse and then incubated for 3 hours at $4^{\circ} \mathrm{C}$. Cultures were carried for $24 \mathrm{~h}$ at $37^{\circ} \mathrm{C}$ or $72 \mathrm{~h}$ at $30^{\circ} \mathrm{C}$ for bacterial and fungal strains, respectively. The diameters of growth inhibition zones were measured for the evaluation of antimicrobial activity. Moreover, Ampicillin (20 $\mathrm{mg} / \mathrm{mL}$ ) and carbendazim $(0.5 \mathrm{mg} / \mathrm{mL})$ were used as positive controls for bacterial and fungal strains, respectively. All tests were done in triplicates and the results were averaged.

\section{Minimum inhibitory concentration (MIC) determination}

The minimum inhibitory concentration (MIC) of 14 lipopeptides was determined by liquid growth inhibition assay in a microtiter plate well (Froidevaux et al. 2001). MIC is defined as the lowest concentration of lipopeptides that completely inhibits the tested strain growth. Indeed, $0.1 \mathrm{~mL}$ of cell suspension were distributed in a microtiter plate well and then an equal volume of serial dilution of lipopeptides, made from $20 \mathrm{mg} / \mathrm{mL}$ solution, was added. The cells were enumerated on nutrient agar medium before and after incubation at $37^{\circ} \mathrm{C}$ for $24 \mathrm{~h}$.

\section{Effect of 14 lipopeptides on F. solani mycelial growth and morphology}

To evaluate the effect of 14 lipopeptides on the growth of $F$. solani, $10 \mathrm{ml}$ of PDA medium containing 14 lipopeptides at different concentrations $(0.5,3.0$ and $5.0 \mathrm{mg} / \mathrm{mL}$ ) were spread on Petri dishes (diameter 6 $\mathrm{cm})$. After solidification, an agar disk $(6 \mathrm{~mm})$ containing the mycelium of $F$. solani was deposited in the center of each Petri dish. After 10 days of incubation at $30^{\circ} \mathrm{C}$, the mycelial growth inhibition (MGI) was calculated according to the following formula:

MGI $(\%)=\frac{\text { diameter of fungal colony in control }- \text { diameter of fungal in treatment }}{\text { diameter of fungal colony in control }} \times 100$

To investigate the effect of 14 lipopeptides on the mycelium morphology, a microscopic observation of mycelium near the zone of inhibition was carried ( $\times 40$ magnifications). Non treated mycelium was used as control.

\section{Application of 14 lipopeptides in potato tuber rots biocontrol}

To evaluate the capacity of 14 lipopeptides in the biocontrol of $F$. solani dry rot, potato tubers were surface sterilized in sodium hypochlorite $(0.5 \%)$ for $10 \mathrm{~min}$, washed using sterile distilled water several times and then dried at room temperature. A volume of $0.1 \mathrm{~mL}$ of spore suspension containing $10^{7}$ spores $/ \mathrm{mL}$ of $F$. solani was poured into a well perforated in the tubers with a sterile cork borer. The treatment of potato tubers with different concentrations of 14 lipopeptides was evaluated by two different methods. The preventive method which consisted on the addition of $0.1 \mathrm{~mL} 14$ lipopeptides ( 3 and $5 \mathrm{mg} / \mathrm{mL}$ ) in the 
wells $24 \mathrm{~h}$ before the infection by fungi while in the curative method the lipopeptides solutions were added at $24 \mathrm{~h}$ post infection. Sterile distilled water and the commercial fungicide carbendazim were used instead of I4 lipopeptides as negative and positive control, respectively. Tubers were incubated in sterile plastic bags at $30^{\circ} \mathrm{C}$ for 15 days at high relative humidity. Meanwhile, the rot development was evaluated by measuring the diameter of $F$. solani spreading lesions. After treatment, tubers were longitudinally cut and the parameters of dry rot induced (maximal width (w) and depth (d)) were recorded. The penetration of the pathogen into tubers was measured as follow (Lapwood et al. 1984).

Penetration $(\mathrm{mm})=\left(\frac{w}{2}+(d-p)\right) / 2$

Where:

$w$ width of dry rot $(\mathrm{mm})$

$d$ depth of the dry rot $(\mathrm{mm})$

$p$ depth of the inoculation well $(\mathrm{mm})$

\section{Statistical analysis}

The data reported here were mean values with standard deviation. Mean values of three biological replicates obtained from each experiment were compared using the Tukey's HSD tests. Moreover, Pearson's correlation coefficient was employed to calculate the correlations between data. All analyses were carried using JMP software version 10 (SAS INSTITUTE).

\section{Results And Discussion}

\section{Detection of NRPS genes in B. mojavensis 14}

PCR was used to detect the presence of NRPS genes in the 14 strain. Positive amplification at expected size was obtained for the tested primers suggesting the presence of five NRPS genes (Fig. 1). BLASTX analysis of each amplified NRPS gene sequences (Table 2) showed that the fragment amplified by As1F/ Ts2-R primers pair showed $91 \%$ identity with surfactin synthase gene from Bacillus subtilis, which is characterized as surfactin-producing strains (Duitman et al. 1999). Similarly, amplified fengycin DNA fragment (primers Af2-F/ Tf1-R) shared high similarity (95\%) with fengycin synthetase from B. subtilis (Table 2). Moreover, PCR fragments corresponding to Bacillomycins, Mycosubtilin and Kurstakin showed significant homology with different peptide synthetases with a homology higher than $88 \%$ (Table 2). These founding suggested that 14 strain could produce surfactin and fengycin. Indeed, previous HPLC analysis revealed that surfactin is the major compound in the lipopeptides mixture produced by 14 strain (Ghazala et al. 2017). In this sense, the detection of NRPS genes is correlated with the nature of produced lipopeptides and their biological activities. the Bacillus sp. strain III4 which produced diverse antifungal lipopeptides against Botrytis cinerea, Fusarium oxysporum and Rhizoctonia solani also displayed 
positive PCR results for the presence of NRPS genes encoding to bacillomycin, surfactin, fengycin and mycosubtilin (El Arbi et al. 2016). Besides, mass spectrometry analysis of lipopeptides from Bacillus strains SS-12.6 showed the presence of a lipopeptide compound corresponding to surfactin which was linked to the presence of PCR products related to genes involved in synthesis of iturins and surfactins (Dimkic et al. 2013). Furthermore, Bacillus amyloliquefaciens An6 lipopeptides exhibited an antioxidant and antimicrobial activities produced multiple lipopeptides belonging to surfactin, iturin, and fengycin families (Ben Ayed et al. 2016). The nature of produced lipopeptides by An6 and their biological activities are in correlation with the positive detection of surfactin, fengycin, and bacillomycin genes in this strain was also reported (Ben Ayed et al. 2016).

Table 2

Blast results of sequence fragments obtained by PCR amplification with degenerate primers

\begin{tabular}{|c|c|c|c|c|c|c|}
\hline $\begin{array}{l}\text { Primer } \\
\text { names }\end{array}$ & $\begin{array}{l}\text { Target NRPS } \\
\text { gene }\end{array}$ & $\begin{array}{l}\text { Product } \\
\text { size (bp) }\end{array}$ & BLASTX hit & $\begin{array}{l}\text { Genbank } \\
\text { accession }\end{array}$ & $\begin{array}{l}\text { Identity } \\
\text { (\%) }\end{array}$ & $\begin{array}{l}\text { e- } \\
\text { value }\end{array}$ \\
\hline $\begin{array}{l}\text { As1-F } \\
\text { Ts2-R }\end{array}$ & Surfactins & 419 & $\begin{array}{l}\text { Surfactin } \\
\text { synthetase } \\
\text { (Bacillus subtilis) }\end{array}$ & P27206 & 91 & $\begin{array}{l}1 \mathrm{e}- \\
80\end{array}$ \\
\hline $\begin{array}{l}\text { Af2-F } \\
\text { Tf1-R }\end{array}$ & Fengycins & 443 & $\begin{array}{l}\text { Fengycin } \\
\text { synthetase } \\
\text { (Bacillus subtilis) }\end{array}$ & AAB80955.2 & 95 & $\begin{array}{l}2 e- \\
88\end{array}$ \\
\hline $\begin{array}{l}\text { Abl1-F } \\
\text { Tbl1-R }\end{array}$ & Bacillomycins & 428 & $\begin{array}{l}\text { Peptide synthetase } \\
\text { (Bacillus } \\
\text { mojavensis) }\end{array}$ & WP_010332989 & 88 & $\begin{array}{l}2 \mathrm{e}- \\
70\end{array}$ \\
\hline $\begin{array}{l}\text { Am1-F } \\
\text { Tm1-R }\end{array}$ & Mycosubtilin & 416 & $\begin{array}{l}\text { Peptide synthetase } \\
\text { (Bacillus subtilis) }\end{array}$ & AMA51368.1 & 85 & $\begin{array}{l}1 \mathrm{e}- \\
58\end{array}$ \\
\hline $\begin{array}{l}\text { Aks-F } \\
\text { Tks-R }\end{array}$ & Kurstakins & 1152 & $\begin{array}{l}\text { Peptide synthetase } \\
\text { (Serratia } \\
\text { marcescens) }\end{array}$ & WP_060443815.1 & 96 & $\begin{array}{l}9 \mathrm{e}- \\
135\end{array}$ \\
\hline
\end{tabular}

\section{Antioxidant activity}

\section{DPPH radical scavenging activity}

As a stable free radical, DPPH has been widely employed to evaluate the free radical scavenging capacity of natural compounds by giving hydrogen to form a stable DPPH molecule (Saleh et al. 2010). DPPH radical scavenging activities of 14 lipopeptides and BHA (used as positive control) as showed in Fig. 2a were concentration-dependent. In fact, at $1 \mathrm{mg} / \mathrm{mL}, 14$ lipopeptides showed a potential scavenging effect of $69.25 \%$ which is higher than the scavenging ability of lipopeptides from B. mojavensis A21 which achieved a DPPH radicals scavenging activity of 65\% (Ben Ayed et al. 2015) and similar to the DPPH radical-scavenging activity of lipopeptides from Bacillus subtilis SPB1 which was $70.4 \%$ at the same concentration (Zouari et al. 2016b). Moreover, the $I_{50}$ value of 14 lipopeptides was $0.36 \mathrm{mg} / \mathrm{mL}$. The IC $\mathrm{I}_{50}$ 
obtained here is similar to that reported for lipopeptides from Bacillus methylotrophicus DCS1 which achieved a DPPH scavenging potential of $80.6 \%$ with an $\mathrm{IC}_{50}$ of $0.357 \mathrm{mg} / \mathrm{mL}$ (Jemil et al. 2017). The results suggested that 14 lipopeptides possessed the capacity to donate hydrogen which could be explained by the presence of some active residues in the peptide ring, which acted as electron donor and could react with free radicals of DPPH (Jemil et al. 2017).

\section{Ferric reducing antioxidant power (FRAP) assay}

The reducing powers of 14 lipopeptides was determined and compared to BHA at different oncentrations were showed in Fig. 2b. The ability of $\mathrm{I} 4$ lipopeptides to reduce $\mathrm{Fe}^{3+}$ to $\mathrm{Fe}^{2+}$ was concentration dependent and the reducing power of 14 lipopeptides increased significantly until a concentration of $6 \mathrm{mg} / \mathrm{mL}$ beyond which reducing power seemed to be constant. However, the 14 lipopeptides showed lower reducing power activities compared to BHA at the same concentrations. The reductive capacity of 14 lipopeptides reached 2.0 (A700 nm) at a concentration of $8 \mathrm{mg} / \mathrm{mL}$ which was is slightly higher than those of Bacillus mojavensis A21 lipopeptides which showed the same reducing activity at a concentration of $10 \mathrm{mg} \mathrm{m} / \mathrm{mL}$ (Ben Ayed et al. 2015). Furthermore, compared to others lipopeptides from bacillus species, the Ferric reducing power of 14 lipopeptides was lower than those reported for Bacillus methylotrophicus DCS1 (Jemil et al. 2017) and B. subtilis RW-I (Yalcin and Cavusoglu 2010) which reached and reducing ability of $2.0(A 700 \mathrm{~nm})$ at a concentrations of 1.3 and $2.5 \mathrm{mg} / \mathrm{mL}$, respectively. It was reported that the reducing power of lipopeptides is correlated with the presence of functional groups in their structure which act as electron donors such as hydroxyl groups that could react with free radicals to convert them into more stable products (Yalcin and Cavusoglu 2010).

\section{Iron $\left(\mathrm{Fe}^{2+}\right)$ chelating activity}

Iron chelating activity determination showed a dose dependent chelating effect of 14 lipopeptides (Fig. 2c). Indeed, at a concentration of $10 \mathrm{mg} / \mathrm{mL}$, the ferrous-chelating effect of 14 lipopeptides was $76.21 \%$ against $98.25 \%$ obtained with EDTA (positive control). The $\mathrm{IC}_{50}$ values for crude biosurfactant and EDTA were estimated at $0.4 \pm 0.03$ and $0.29 \pm 0.01 \mathrm{mg} / \mathrm{mL}$, respectively. This activity was lower than those reported by Zouari et al. (2016b) which found that the chelating effect of biosurfactant of $B$. subtilis SPB1 and EDTA were $80.32 \%$ and $98.89 \%$, respectively, at a concentration of $1 \mathrm{mg} / \mathrm{mL}$ and those from Bacillus methylotrophicus DCS1 lipopeptides which exhibited a ferrous-chelating activity of $79.8 \%$ at $4 \mathrm{mg} / \mathrm{mL}$ (Jemil et al. 2017). This difference in Iron chelating activity observed among different bacillus species could be explained by the structural differences of lipopeptides produced by each species. Indeed, the differences in the sequence of amino acids and carbon atoms in the fatty acids provide biosurfactants with diverse chemical structures and physiochemical properties (Liu et al. 2015).

\section{DNA nicking assay}

The DNA nicking assay was used to investigate the scavenging ability of 14 lipopeptides against hydroxyl radical generated by the Fenton reaction. Results (Fig. 2d) showed that the plasmid DNA was completely degraded in the presence of hydroxyl radicals generated by the Fenton reaction (Lane 3) compared to the 
native plasmid (Lane 4). The migration profiles of the plasmid pre-incubated with the 14 lipopeptides at 1 $\mathrm{mg} / \mathrm{mL}$ (Lane 1) and $4 \mathrm{mg} / \mathrm{mL}$ (Lane 2) is similar to the control plasmid (Lane 4). This founding suggested that 14 lipopeptides could inhibit the oxidation of DNA by hydroxyl radicals. This results were similar to those reported by Ben Ayed et al. (2016) who showed that lipopeptides from $B$. amyloliquefaciens An6 counteract the oxidative stress produced by Fenton reaction and allowed protection of plasmid DNA against oxidation using the same test (Ben Ayed et al. 2016).

\section{Antimicrobial activity of 14 lipopeptides}

The antibacterial activities of 14 lipopeptides were tested against Gram-positive (S. aureus, $L$. monocytogenes, E. faecalis and M. Iuteus) and Gram-negative (E. coli, P. aeruginosa, K. pneumoniae and $S$. enterica) bacteria according to method of double diffusion in the agar. Ampicillin was used as a positive control. The antibacterial activity was evaluated by the determination of the diameter of growth inhibition zone and the MIC values. Results showed that 14 lipopeptides at a concentration of $20 \mathrm{mg} / \mathrm{mL}$ had antibacterial activity against all strains tested (Table 3 ). The inhibition zones of 14 lipopeptides were between of 8-16 mm and 7-15 mm with Gram-positive and Gram-negative bacteria, respectively. The most resistant strains were E. coli, E. faecalis and L. monocytogenes with DZI of 7, 8 and $10 \mathrm{~mm}$, respectively while the most sensitive strains were $S$. aureus, M. Iuteus, S. enteric and K. pneumonia with a diameter of the inhibition zones of 15, 16, 17 and $15 \mathrm{~mm}$, respectively. Moreover, the strains with the largest inhibition zones showed the lowest MIC values (Table 3). Similarly, Ben Ayed et al. (2016) showed that the lipopeptide of $B$. amyloliquefaciens An6 exhibited a high antibacterial activity against $B$. cereus, $S$. aureus and $E$. coli at a concentration of $2 \mathrm{mg} / \mathrm{mL}$ with DZI of 20,18 and $17 \mathrm{~mm}$, respectively. Regarding antifungal activity, the 14 biosurfactants inhibited the growth of $F$. solani, $R$. solani and $B$. cinerea (Table 3) with inhibition zones of 24 for F. solani, R. solani and $23 \mathrm{~mm}$ for B. cinerea. 
Table 3

Antimicrobial activity of I4 lipopeptides biosurfactants from B. mojavensis

\begin{tabular}{|c|c|c|c|c|}
\hline & Microorganisms & $\begin{array}{l}\text { Inhibition Zones } \\
\text { diameter (mm) }\end{array}$ & $\underset{\mathrm{mL})}{\mathrm{MIC}(\mathrm{mg} /}$ & $\begin{array}{l}\text { Ampicillin Inhibition zones } \\
\text { diameter }(\mathrm{mm})\end{array}$ \\
\hline \multirow{4}{*}{$\begin{array}{l}\text { Gram } \\
+\end{array}$} & S. aureus & $15 \pm 0.91$ (c) & 10 & $35 \pm 2.24$ \\
\hline & E. faecalis & $8 \pm 1.04(a)$ & 20 & $27 \pm 1.13$ \\
\hline & M. luteus & $16 \pm 1.29$ (c) & 1.25 & $28 \pm 2.19$ \\
\hline & $\begin{array}{l}\text { L. } \\
\text { monocytogenes }\end{array}$ & $10 \pm 0.98$ (b) & 20 & $32 \pm 2.29$ \\
\hline \multirow[t]{4}{*}{ Gram- } & E.coli & $7 \pm 0.86(a)$ & 20 & $25 \pm 2.09$ \\
\hline & S. enteric & $17 \pm 1.6$ (c) & 2.5 & $35 \pm 2.6$ \\
\hline & K. pneumonia & $15 \pm 0.9$ (c) & 20 & $24 \pm 1.92$ \\
\hline & & & & $\begin{array}{l}\text { Carbendazim Inhibition zones } \\
\text { diameter (mm) }\end{array}$ \\
\hline \multirow[t]{3}{*}{ Fungi } & F. solani & $24 \pm 1.2(\mathrm{de})$ & nd & $30 \pm 2.15$ \\
\hline & B. cinerea & $23 \pm 1$ (de) & nd & $25 \pm 1.11$ \\
\hline & R. solani & $24 \pm 1.1(\mathrm{de})$ & nd & $32 \pm 2.21$ \\
\hline
\end{tabular}

We determined Pearson's correlation coefficient to establish the relationship between the antioxidant and the antimicrobial activites. The obtained results have shown significant correlations between the antioxidant activity and the antimicrobial activity of $\mathrm{I} 4$ lipopeptides $\left(0.95 \leq \mathrm{R}^{2} \geq 0.99, P<0.01\right)$. Indeed, the highest correlation was obtained between MIC value and Ferrous ion chelating $\left(R^{2}=0.99, P<0.01\right)$. Similarly significant correlation was observed between antimicrobial activity and DPPH scavenging activity $\left(R^{2}=0.95, P<0.01\right)$. These correlations could be explained by the capacity of lipopeptides to neutralization of the free radicals by acting as an electron donor and their ability to permeate the cell membrane of the target organism leading to cell death. Indeed, the major compound in the 14 biosurfactants was surfactin (Ghazala et al. 2018). Moreover, it was reported that the major compound in lipopetides from Bacillus subtilis RW-I is surfactin and the crude biosurfactant showed powerful scavenging properties (Yalcin and Cavusoglu 2010). It was reported that lipopeptides from B. mojavensis A21 contained surfactin and fengycin as major compounds (Hmidet et al. 2017) and has both antimicrobial and antioxidant activities (Ben Ayed et al. 2015). Snook et al. (2009) reported that Bacillus mojavensis RRC 101 produced surfactin which was effective in the biocontrol of Fusarium verticillioides in maize. The observed antibacterial and antifungal activities of I4 blipopeptides corroborated the PCR 
detection of NRPS genes. These findings suggested the synergistic antimicrobial inhibitory effects of different antimicrobial lipopeptides produced by $B$. mojavensis 14 .

\section{The effect of 14 biosurfactants on mycelial growth of $F$. solani}

Fusarium dry rot is a postharvest disease which caused severe potato tubers losses could be caused by several Fusarium spp among them F. solani remains the most prevalent (Daami-Remadi et al. 2006). In this work we are considering the use of crude 14 lipopeptides as cost effective biocontrol agent of this disease instead of chemical control. The growth inhibition assay showed that the 14 lipopeptides possessed an important antifungal activity against $F$. solani with an inhibition zone of $24 \mathrm{~mm}$ (Table 3). Further, the growth of $F$. solani were evaluated during 10 days in the presence of different lipopeptides concentrations $(0.5,3$ and $5 \mathrm{mg} / \mathrm{mL})$ in comparison to the mock control without biosurfactants. Results showed that the 14 lipopeptides effectively inhibited the growth of $F$. solani compared to the control (Fig. 3a). The micelial growth inhibitions (MGI) obtained here were about 25.2, 51 and $72 \%$ in the presence of 14 lipopeptides at $0.5,3$ and $5 \mathrm{mg} / \mathrm{mL}$, respectively. It was reported that Bacillus subtilis strain Bs-Cach harbour in vitro antagonism with an inhibition of mycelial growth between 50.33 and $51.93 \%$ against tow F. solani strains (ICA-3 and ICA-4) which was correlated with the synthesis of lipopeptides belonging to the family of iturins and also the positive detection of presence of iturin (ItuA), surfactin (SrfC), and fengycin (FenD) genes in this strains (Mendez-Trujillo et al. 2018). Bacillus subtilis SPB1 biosurfactants, reported contain different lipopeptide compounds such surfactin, iturin and fengycin, totally inhibits the growth of $F$. solani at $3 \mathrm{mg} / \mathrm{mL}$ and Rhizoctonia solani at $4 \mathrm{mg} / \mathrm{mL}$ (Mnif et al. 2016). To affirm the antifungal potency of 14 lipopeptides, mycelium of $F$. solani was microscopically observed near the zone of inhibition (Fig. 3b). In fact, the non-treated control showed articulate hyphae with normal mycelium and smooth surfaces (Fig. 3b) while the treated mycelium showed irregular shape with excessive lyses and destructed spores. Moreover, no fungal growth was observed with $5 \mathrm{mg} / \mathrm{mL}$ of lipopeptides which suggested total destruction of the spores ensuring high efficacy of antagonistic activity. This observation suggested that 14 biosurfactants acted on the cell surface by the potent permeabilizing activity leading to cellular death. Similarly the cell lysis of the pathogenic fungi $F$. solani when treated by SPB1 biosurfactants was earlier reported (Mnif et al. 2015).

\section{Application of 14 biosurfactants in potato tuber rots biocontrol}

The efficacy of 14 biosurfactants in the treatment of potato tuber rot caused by F. solani was investigated in vivo (Fig. 4). For this purpose, both curative and protective treatments were carried out. Commercial antifungal agent carbendazim was used as positive control (Fig. 4a). Results showed that 14 lipopeptides were effective in the biocontrol of the disease at all tested concentrations in both curative and protective treatments (Fig. 4a and 4b). Penetration values for controls and the treated tubers revealed that the lipopeptides reduced the penetration of the pathogen up to $80 \%$ at $5 \mathrm{mg} / \mathrm{mL}$ in preventive treatment while in curative one the reduction was almost $67 \%$ (Fig. 4c). Moreover, significant differences were observed between the tested concentrations in both the treatments. Indeed, the reduction of the fungus penetration was significantly more effective with $5 \mathrm{mg} / \mathrm{mL}$ than $3 \mathrm{mg} / \mathrm{mL}$. Besides, at the same concentration (5 
$\mathrm{mg} / \mathrm{mL})$, the preventive treatment was more efficient than the curative one $(P \leq 0.05)$. However, lipopeptides from $B$. mojavensis 14 was less effective compared to the commercial antifungal agent as it reduced $90 \%$ of the fungus penetration using the preventive treatment. This result is in accordance with the previous report that preventive treatment was more effective than preventive treatment in the biocontrol of $F$. solani in potato tuber using biosurfactants from B. subtilis SPB1 (Mnif et al. 2015). Fengycin from Bacillus subtilis M4 was effectively used in the biocontrol of Pythium ultimum and Botrytis cinerea that caused bean root rot and apple mold disease, respectively (Ongena et al. 2005). Similarly, lipopeptides from Bacillus subtilis NCD-2 effectively reduced the cotton seedling damping-off disease caused by $R$. solani (Guo et al. 2014). Besides, FPLC analysis revealed that the antifungal compound of Bacillus subtilis NCD-2 was fengycin homologs witch was positively correlated with the PCR detection of fenC gene in B. subtilis NCD-2 (Guo et al. 2014). Torres et al. (2017) showed that lipopeptides from Bacillus amyloliquefaciens PGPBacCA1 harbour antifungal activity against several phytopathogen fungi. These authors also reported that PGPBacCA1 lipopeptides inhibited the growth of Rhizoctonia solani up to $73 \%$ and also reported that surfactin, iturin and fengycin were identified as the main responsible for the antagonistic effect. Moreover, crude biosufactants from Bacillus licheniformis significantly reduced the incidence of root rot in faba bean caused by Rhizoctonia solani AG-4 (Akladious et al. 2018).

\section{Conclusion}

In the present study we explored the in vitro antioxidant and antimicrobial activities of lipopeptides from B. mojavensis 14 and its efficiency in the biocontrol of potato dry rot caused by $F$. Solani. The results of our work demonstrate that $B$. mojavensis 14 could produce different type of lipopeptides according to the positive detection of five NRPS genes. 14 lipopeptides were found to exhibit strong antioxidant and antimicrobial activities Moreover, 14 lipopeptides effectively reduced the potato tuber dry rots caused by $F$. solani using preventive treatment. Considered together, results obtained here suggested the potential application of 14 lipopeptides in potato tubers treatment before their storage.

\section{Declarations}

\section{Acknowledgement}

This work was funded by the Ministry of Higher Education and Scientific Research-Tunisia.

\section{Conflict of interest}

The authors declare that they have no competing interests.

\section{References}

1. Abderrahmani A et al. (2011) Bioinformatics and molecular approaches to detect NRPS genes involved in the biosynthesis of kurstakin from Bacillus thuringiensis. Appl Microbiol Biotechnol 
92:571-581 doi: 10.1007/s00253-011-3453-6

2. Akladious SA, Gomaa EZ, El-Mahdy OM (2018) Efficiency of bacterial biosurfactant for biocontrol of Rhizoctonia solani (AG - 4) causing root rot in faba bean (Vicia faba) plants. European Journal of Plant Pathology doi: 10.1007/s10658-018-01639-1

3. Akpa E et al. (2001) Influence of culture conditions on lipopeptide production by Bacillus subtilis. Appl Biochem Biotechnol 91-93:551-561

4. Ben Ayed $\mathrm{H}$ et al. (2015) Wound healing and in vitro antioxidant activities of lipopeptides mixture produced by Bacillus mojavensis A21. Process Biochemistry 50:1023-1030 doi:

10.1016/j.procbio.2015.02.019

5. Ben Ayed H, Hmidet N, Béchet M, Jacques P, Nasri M (2016) Identification and natural functions of cyclic lipopeptides from Bacillus amyloliquefaciens An6. Engineering in Life Sciences 00:1-19 doi: $10.1002 /$ elsc. 201600050

6. Berghe DAV, Vlietnick AJ, Dey PM, Harborne JB (1991) Screening methods for antibacterial and antiviral agents from higher plants, In methods in plant biochemistry. Academic press: London, Vl:4769

7. Bersuder P, Hole M, Smith G (1998) Antioxidants from a heated histidine-glucose model system. I: Investigation of the antioxidant role of histidine and isolation of antioxidants by high-performance liquid chromatography. Journal of the American Oil Chemists Society 75:181-187 doi: DOI 10.1007/s11746-998-0030-y

8. Daami-Remadi M, Ayed F, Jabnoun-Khiareddine H, Hibar K, El Mahjoub M (2006) Comparative susceptibility of some local potato cultivars to four Fusarium species causing tuber dry rot in Tunisia. Journal of Plant Sciences 1:306-314

9. Dimkic l et al. (2013) Characterization and evaluation of two Bacillus strains, SS-12.6 and SS-13.1, as potential agents for the control of phytopathogenic bacteria and fungi. Biological Control 65:312321 doi: 10.1016/j.biocontrol.2013.03.012

10. Duitman EH et al. (1999) The mycosubtilin synthetase of Bacillus subtilis ATCC6633: A multifunctional hybrid between a peptide synthetase, an amino transferase, and a fatty acid synthase. Proceedings of the National Academy of Sciences of the United States of America 96:13294-13299 doi: DOI 10.1073/pnas.96.23.13294

11. El Arbi A et al. (2016) The Tunisian oasis ecosystem is a source of antagonistic Bacillus spp. producing diverse antifungal lipopeptides. Research in Microbiology 167:46-57 doi: 10.1016/j.resmic.2015.09.003

12. Froidevaux $R$ et al. (2001) Antibacterial activity of a pepsin-derived bovine hemoglobin fragment. Febs Letters 491:159-163 doi: Doi 10.1016/S0014-5793(01)02171-8

13. Ghazala I, Bouallegue A, Haddar A, Ellouz-Chaabouni S (2018) Characterization and production optimization of biosurfactants by Bacillus mojavensis 14 with biotechnological potential for microbial enhanced oil recovery. Biodegradation doi: 10.1007/s10532-018-9844-y 
14. Ghazala I, Bouassida M, Krichen F, Manuel Benito J, Ellouz-Chaabouni S, Haddar A (2017) Anionic lipopeptides from Bacillus mojavensis 14 as effective antihypertensive agents: Production, characterization, and identification. Engineering in Life Sciences 17:1244-1253 doi: $10.1002 /$ elsc. 201700020

15. Guo Q et al. (2014) Fengycin produced by Bacillus subtilis NCD-2 plays a major role in biocontrol of cotton seedling damping-off disease. Microbiol Res 169:533-540 doi: 10.1016/j.micres.2013.12.001

16. Hmidet N, Ben Ayed H, Jacques P, Nasri M (2017) Enhancement of Surfactin and Fengycin Production by Bacillus mojavensis A21: Application for Diesel Biodegradation. Biomed Res Int 2017:5893123 doi: 10.1155/2017/5893123

17. Jemil N, Manresa A, Rabanal F, Ben Ayed H, Hmidet N, Nasri M (2017) Structural characterization and identification of cyclic lipopeptides produced by Bacillus methylotrophicus DCS1 strain. J Chromatogr B Analyt Technol Biomed Life Sci 1060:374-386 doi: 10.1016/j.jchromb.2017.06.013

18. Lapwood DH, Read PJ, Spokes J (1984) Methods for assessing the susceptibility of potato tubers of different cultivars to rotting by Erwinia carotovora subspecies atroseptica and carotovora. Plant Pathology 33:13-20 doi: 10.1111/j.1365-3059.1984.tb00581.x

19. Liu JF, Mbadinga SM, Yang SZ, Gu JD, Mu BZ (2015) Chemical structure, property and potential applications of biosurfactants produced by Bacillus subtilis in petroleum recovery and spill mitigation. Int J Mol Sci 16:4814-4837 doi: 10.3390/ijms16034814

20. Liu XY, Yang SZ, Mu BZ (2008) Isolation and characterization of a C12-lipopeptide produced by Bacillus subtilis HSO 121. J Pept Sci 14:864-875 doi: 10.1002/psc.1017

21. Mendez-Trujillo V, Carrillo-Beltran M, Gonzalez-Mendoza D, Gutierrez-Miceli F, Valdez-Salas B (2018) Antifungal Activity and Presence of Lipopeptides Genes in Bacillus subtilis Isolated from the Rhizosphere of Pluchea sericea. Iranian Journal of Science and Technology Transaction a-Science 42:415-419 doi: 10.1007/s40995-016-0110-z

22. Mnif I et al. (2016) Purification and identification of Bacillus subtilis SPB1 lipopeptide biosurfactant exhibiting antifungal activity against Rhizoctonia bataticola and Rhizoctonia solani. Environ Sci Pollut Res Int 23:6690-6699 doi: 10.1007/s11356-015-5826-3

23. Mnif I, Hammami I, Triki MA, Azabou MC, Ellouze-Chaabouni S, Ghribi D (2015) Antifungal efficiency of a lipopeptide biosurfactant derived from Bacillus subtilis SPB1 versus the phytopathogenic fungus, Fusarium solani. Environ Sci Pollut Res Int 22:18137-18147 doi: 10.1007/s11356-015-50056

24. Nguyen DMC, Seo DJ, Park RD, Lee BJ, Jung WJ (2013) Chitosan beads combined with Terminalia nigrovenulosa bark enhance suppressive activity to Fusarium solani. Industrial Crops and Products 50:462-467 doi: 10.1016/j.indcrop.2013.07.060

25. Ongena $M$, Jacques $P$, Toure $Y$, Destain J, Jabrane A, Thonart $P$ (2005) Involvement of fengycin-type lipopeptides in the multifaceted biocontrol potential of Bacillus subtilis. Appl Microbiol Biotechnol 69:29-38 doi: 10.1007/s00253-005-1940-3 
26. Saleh MA, Clark S, Woodard B, Deolu-Sobogun SA (2010) Antioxidant and Free Radical Scavenging Activities of Essential Oils. Ethnicity \& Disease 20:78-82

27. Snook ME, Mitchell T, Hinton DM, Bacon CW (2009) Isolation and characterization of leu7-surfactin from the endophytic bacterium Bacillus mojavensis RRC 101, a biocontrol agent for Fusarium verticillioides. J Agric Food Chem 57:4287-4292 doi: 10.1021/jf900164h

28. Strange RN, Scott PR (2005) Plant disease: a threat to global food security. Annu Rev Phytopathol 43:83-116 doi: 10.1146/annurev.phyto.43.113004.133839

29. Tabbene $O$ et al. (2012) Antioxidative and DNA protective effects of bacillomycin D-like lipopeptides produced by b38 strain. Appl Biochem Biotechnol 168:2245-2256 doi: 10.1007/s12010-012-9933-z

30. Thompson MD et al. (2009) Functional food characteristics of potato cultivars (Solanum tuberosum L.): Phytochemical composition and inhibition of 1-methyl-1-nitrosourea induced breast cancer in rats. Journal of Food Composition and Analysis 22:571-576 doi: 10.1016/j.jfca.2008.09.002

31. Torres MJ, Brandan CP, Sabate DC, Petroselli G, Erra-Balsells R, Audisio MC (2017) Biological activity of the lipopeptide-producing Bacillus amyloliquefaciens PGPBacCA1 on common bean Phaseolus vulgaris L. pathogens. Biological Control 105:93-99 doi: 10.1016/j.biocontrol.2016.12.001

32. Toth IK et al. (2011) Dickeya species: an emerging problem for potato production in Europe. Plant Pathology 60:385-399 doi: 10.1111/j.1365-3059.2011.02427.x

33. Yalcin E, Cavusoglu K (2010) Structural Analysis and Antioxidant Activity of a Biosurfactant Obtained from Bacillus subtilis RW-I. Turkish Journal of Biochemistry-Turk Biyokimya Dergisi 35:243247

34. Yildirim A, Mavi A, Kara AA (2001) Determination of antioxidant and antimicrobial activities of Rumex crispus L. extracts. Journal of Agricultural and Food Chemistry 49:4083-4089 doi: $10.1021 / \mathrm{jf} 0103572$

35. Zouari I, Jlaiel L, Tounsi S, Trigui M (2016a) Biocontrol activity of the endophytic Bacillus amyloliquefaciens strain CEIZ-11 against Pythium aphanidermatum and purification of its bioactive compounds. Biological Control 100:54-62 doi: 10.1016/j.biocontrol.2016.05.012

36. Zouari R, Moalla-Rekik D, Sahnoun Z, Rebai T, Ellouze-Chaabouni S, Ghribi-Aydi D (2016b) Evaluation of dermal wound healing and in vitro antioxidant efficiency of Bacillus subtilis SPB1 biosurfactant. Biomed Pharmacother 84:878-891 doi: 10.1016/j.biopha.2016.09.084

\section{Figures}




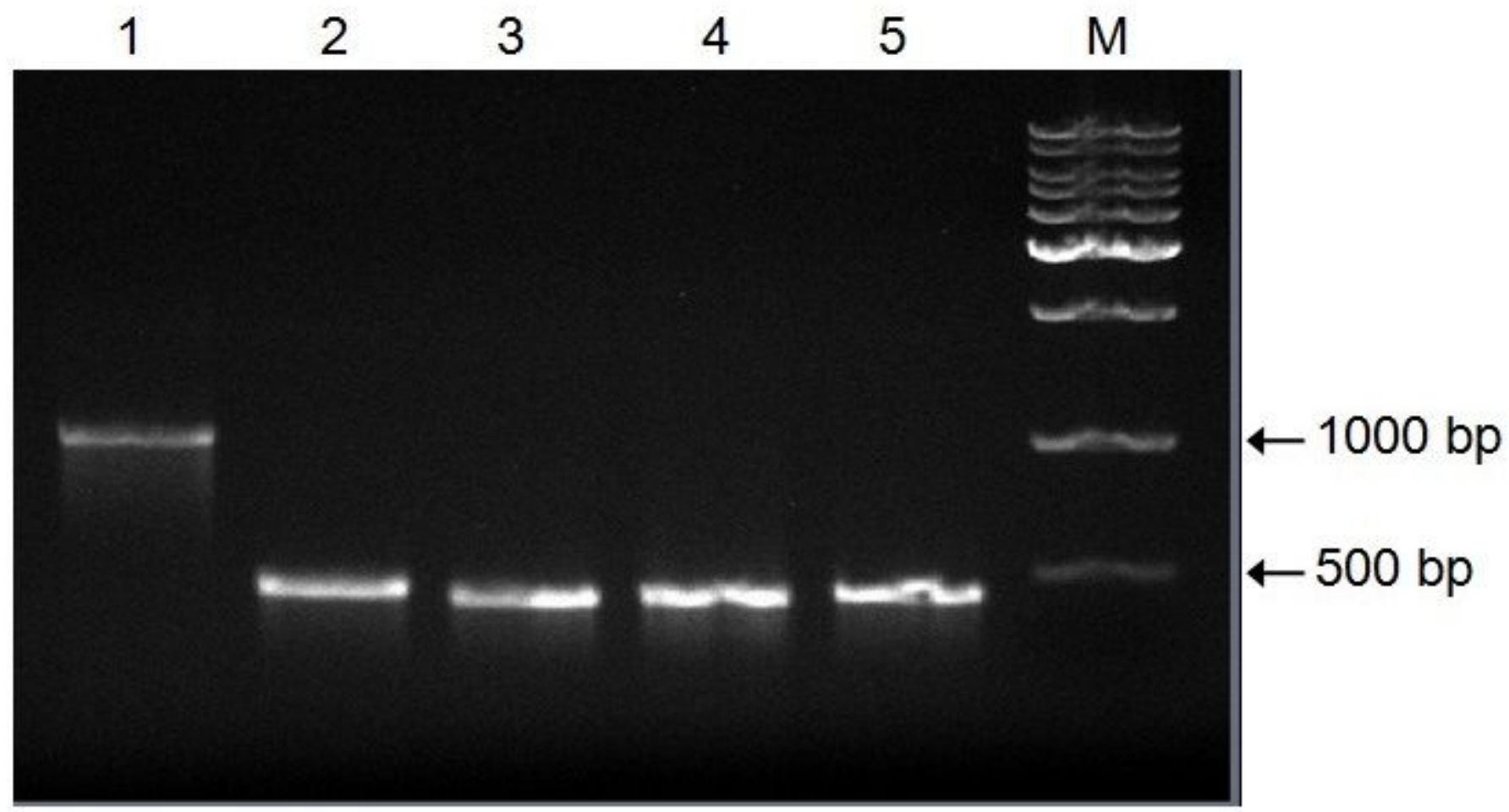

\section{Figure 1}

PCR detection of NRPS genes in B. mojavensis 14. M: molecular weight marker GeneRuler $1 \mathrm{~kb}$ DNA Ladder (Thermo Scientific), Lane 1: Kurstakins primers (Aks-F/Tks-R), Lane 2: Fengycin primers (Af2F/Tf1-R), Lane 3: Surfactins primers (As1-F/Ts2-R), Lane 4: Mycosubtilin primers (Am1- F/Tm1-R) and Lane 5: Bacillomycins primers (Abl1-F/Tbl1-R) 

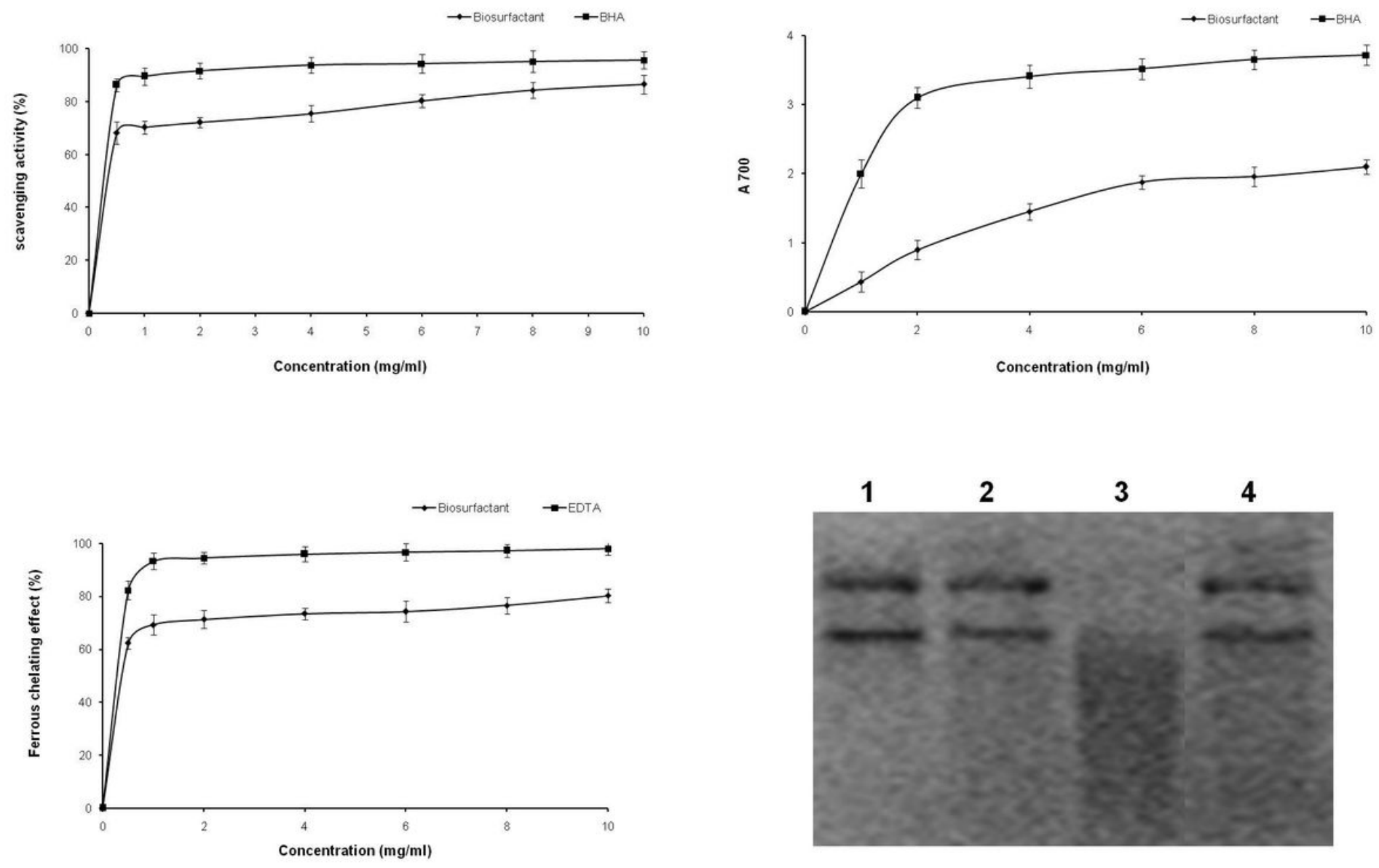

\section{Figure 2}

Antioxidant activities of 14 biosurfactants. (a) DPPH radical scavenging activity, (b) reducing power essay, (c) metal chelating effect and (d) gel electrophoresis pattern of the empty PGEM-T easy plasmid incubated with Fenton's reagent in the presence and absence of 14 lipopeptides. Lanes 1 and 2: Fenton's reagent + DNA + $1 \mathrm{mg}$ and $4 \mathrm{mg} / \mathrm{mL}$ of 14 lipopeptides, respectively, lane 3: DNA sample incubated with Fenton's reagent and lane 4: untreated control: native pGEM-T easy plasmid $(0.5 \mu \mathrm{g})$ 
I4 biosurfactant
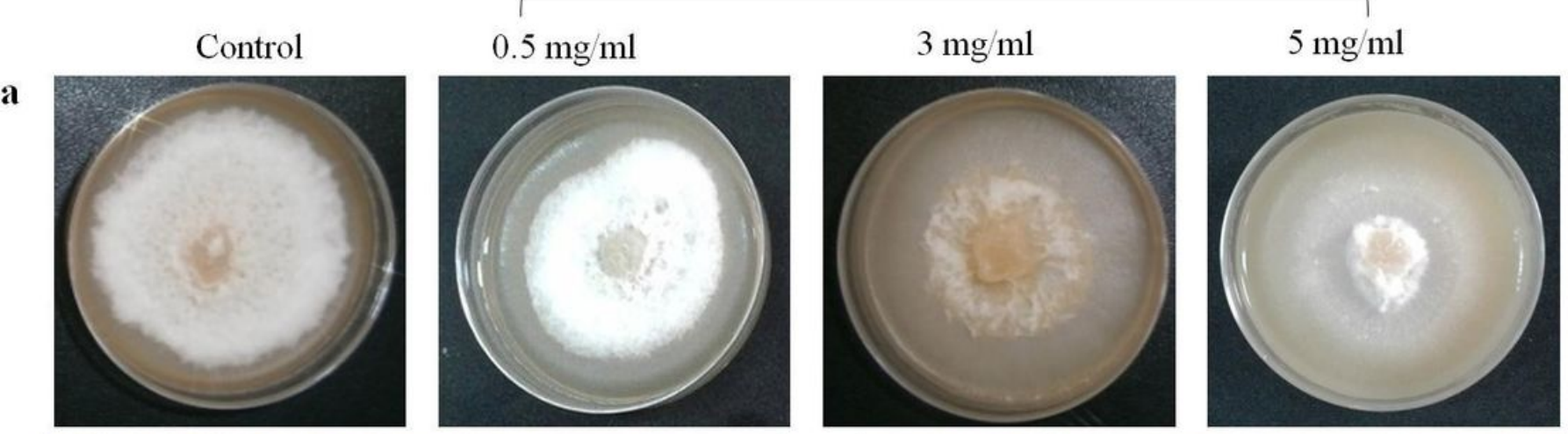

b
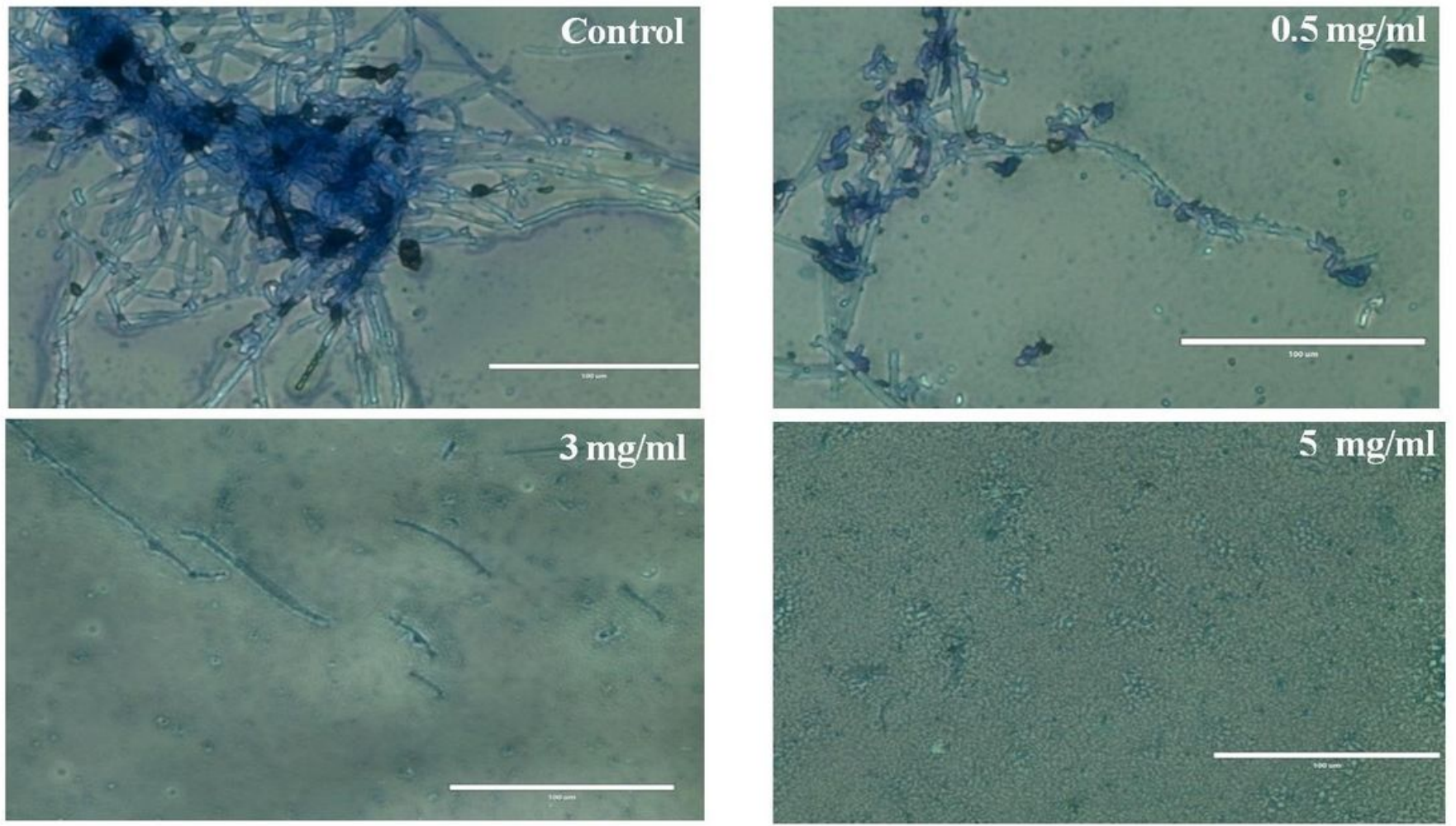

\section{Figure 3}

Antifungal activity of 14 biosurfactants against $F$. solani: (a) effect of increasing concentration on the antifungal potency. (b) Effect of 14 biosurfactants on F. solani mycelial growth: representative microscopic pictures (10×40 magnifications) of mycelium and spores grown in medium 


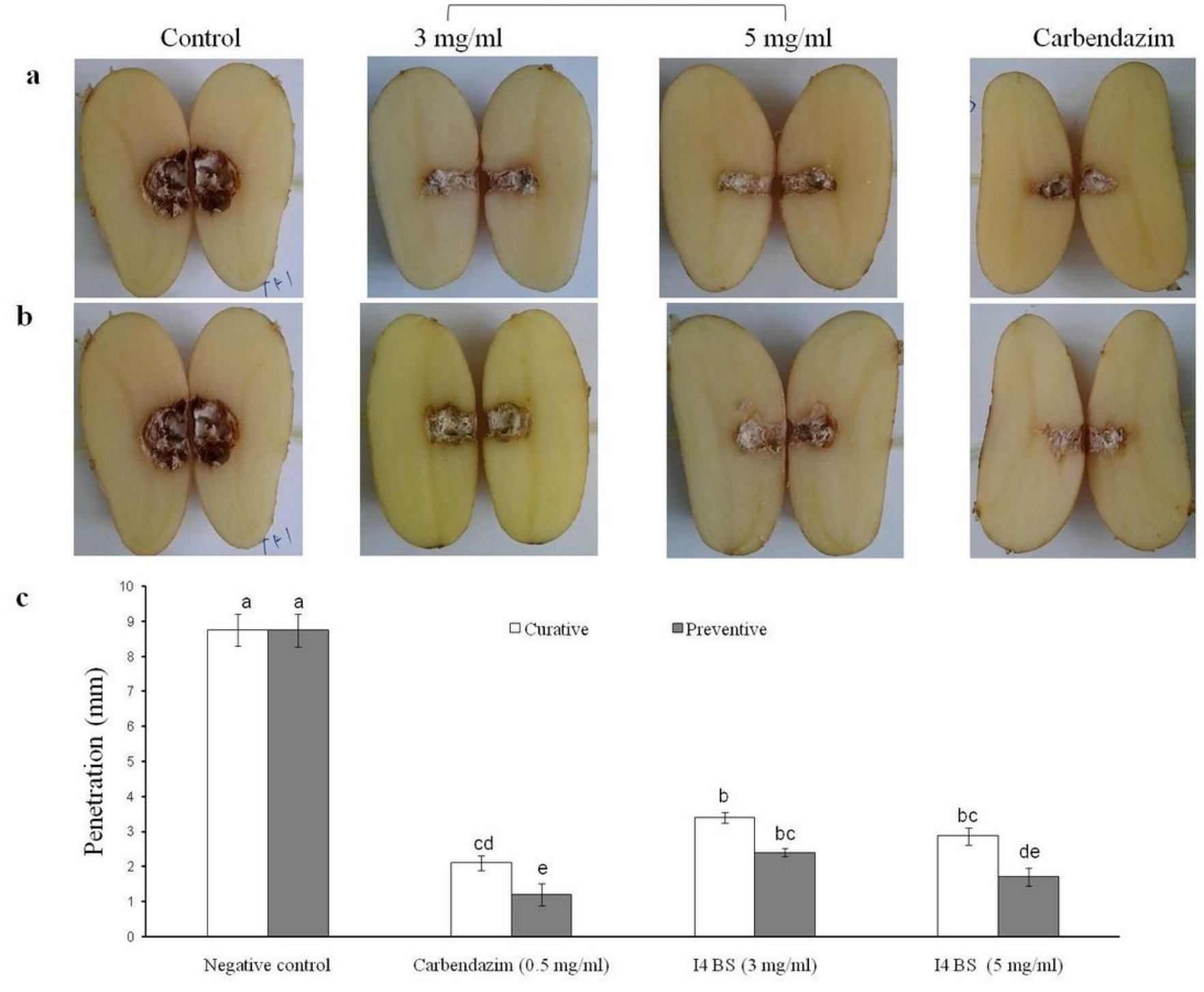

\section{Figure 4}

Effect of B. mojavensis 14 biosurfactants lipopeptides and carbendazim treatment on potato dry soft rot development caused by $F$. solani after 15 days of incubation at $30{ }^{\circ} \mathrm{C}$ using preventive (a) and curative (b) treatment. (c) : Effect of 14 lipopeptides and carbendazim treatment on the penetration of $F$. solani into potato tubers in both preventive and curative treatments. Value reported were means $\pm S D$, histograms highlighted with different letters indicates that the difference between two means is statistically significant $(P<0.05)$ 